\title{
Homestay Development With Asean Homestay Standard Approach In Nglanggeran Tourism Village, Yogyakarta, Indonesia
}

\author{
Retno Budi Wahyuni \\ Sekolah Tinggi Pariwisata Bandung \\ Bandung, Indonesia \\ naniekretno@gmail.com
}

\author{
Faisal F.P. \\ Sekolah Tinggi Pariwisata Bandung \\ Bandung, Indonesia \\ faisalpuksi@gmail.com
}

\begin{abstract}
Homestay play important role as one of tourist facilities that can attracts tourists, both domestic and foreign tourists. Tourists who stay in homestay can interact with local people and learn the traditional culture. Unfortunately, it remains disregarded especially in the domestic market, and also fails to meet the customers' expectation of both domestic and foreign tourists. Therefore, international standard of homestay business management should be applied to meeting the requirement of national strategy and making the business sustainable. The main objective of this research is to find out about homestay management in Nglanggeran Tourism Village related with ASEAN Homestay Standard. Homestays management characteristics in Nglanggeran Tourism Village were identified with ASEAN Homestay Standard indicators. The indicators are divided into nine criteria, namely Host, Accommodation, Activities, Management, Location, Hygiene and Cleanliness, Safety and Security, Marketing and Promotion, and Sustainability Principles. This research used descriptive qualitative research method. Data collection techniques in this research were use observation, interviews, documentation studies, and literature studies. In-depth interview to three homestay owners, one tourism village management, and one local government representative were conducted. Check-list assessment from ASEAN Homestay Standard was used as the basis of semi-structured interview guidelines. Based on the results of analysis, it revealed that Nglanggeran Tourism Village has not been able to maximize the existence of the homestay optimally. Homestay owners and tourism village management should take some points into consideration, including homestays capacities, official registration, integration between marketing promotions with homestay facilities and activities, homestay representative in Nglanggeran Tourism Village management, and hygiene standard.
\end{abstract}

Keywords - Homestay, ASEAN Homestay Standard, Tourism Village, Nglanggeran

\section{INTRODUCTION}

In line with increasing incomes, better infrastructure, and evolving ways of tourism marketing, people nowadays travel in greater numbers and frequency than before. To ensure the sustainability of tourism industry given the increase in tourist arrivals (domestic and international), stakeholders in tourism industry must ensure that the services which grow and diverse must be provided adequately for tourists. Diversified tourism products and services must be made available to meet tourist needs. The increased desire for nature-based and agro-tourism has improved tourism activities in rural areas. Tourists of this category definitely want to stay at places that give them access to the natural and rural environments. At the same time these activities can provide business and employment opportunities to local communities.

Indonesia is rich with natural attraction and cultural heritage in rural areas. These assets can provide an opportunity for rural communities to be directly involved in tourism programs. The involvement of local people in tourism activities can help them to improve their economic, social and cultural quality. In this way, rural tourism is able to boost the economy of rural communities in particular, and helps to solve the problem of poverty and unemployment in general. Tourism village is a rural area which offers the atmosphere of authenticity countryside either of the socioeconomic, socio-cultural, customs, daily life, has the architecture and structure of the village spatial characteristic, or economic activities are unique and interesting and have the potential to be developed with the various components of tourism.

Among the main services needed by tourists are accommodation facilities. Variation in tourists' needs certainly creates demand for different types of accommodation according to their budgets and tastes. Supply of various types of accommodation such as luxury hotels, budget hotels, chalets, rest houses, apartments, homestays and the like would provide a wide range of choices for tourists to meet their taste and budget. A key feature in rural tourism is the widespread availability of opportunities for visitors to stay overnight with a host family in a rural community. Rural homestays allow guests to catch a glimpse of the daily lives of village residents and therefore serve as a means of experiencing a local community in ways that differ from conventional tourism interactions and settings (Kontogeorgopoulos, et. al, 2015). Homestay can be an alternative form of accommodation that features basic 
standards and takes place in small, and often remote, rural communities, homestays appeal to a very small and specific niche of tourists.

Homestay business is currently rapidly growing in Indonesia, especially since Ministry of Tourism Republic of Indonesia in 2017 put it as priority and important in tourism facility development in Indonesia. Therefore, the homestay program is an important and integral method to improve socio-economic condition in rural areas. Despite the difficulties in the involvement of homestay program as stated by Kayat and Ashikin (2006) due to lack of managing experience, knowledge and skills, the development of community-based tourism activities can strengthen community institutions (Brohman, 1996). Mutual cooperation is likely be nurtured and locals will be able to provide various tourism activities that can be presented to tourists. At the same time, cooperation between the government and the local community of the homestay program will help to improve the socio-economic of the involved community.

The study by Taylor (1995) also demonstrated the importance of community involvement in the current development of the tourism industry. In fact, this involvement is often regarded as the key to community sustainable development where the community is expected to share all the benefits (such as job opportunities and income) from the development of homestay program within the community. Thus, there is a need for the community to be involved in tourism development. Such involvement is not only helping the development of tourism industry but more importantly it will improve the local community's quality of life. In the long run it will be able to guarantee their livelihood sustainability (Clayton et.al., 1998). Realizing the importance of local communities' involvement in the development of tourism industry, this study aimed to evaluate community participation in the development of homestay tourism.

Nglanggeran village, Yogyakarta, Indonesia is a tourism village that has potential natural attractions is unique and attractive form: Ancient Volcano, Embung (lake) Nglanggeran, and Orchard Nglanggeran. Nglanggeran Tourism Village which provides eco-tourism and cultural tourism experiences for tourist is expected can improve the economy of the local community. Community empowerment is an attempt to enable independent with encouraging, motivating and raise awareness of its potential to be more efficient and effective.

The response of local community in providing the needs of visitors is also great, many locals who started to open businesses such as foods, drinks, handicrafts, and homestays. They recognized that tourism can give extra additional income other than agriculture by providing homestay for tourists (Hermawan, 2016). In line with that, homestay development in Nglanggeran should match with international standard, especially when this tourism village was elected to be the best Tourism Village in the Southeast Asian region in ASEAN Community Tourism Award 2017. Homestay standard that were accepted in South East Asia is ASEAN Homestay Standard.
The main purpose for this research is to address how Nglanggeran Tourism village, as the best Tourism Village in the Southeast Asian region in ASEAN Community Tourism Award 2017, develop its homestay comply with ASEAN Homestay Standard indicators. Therefore, indicators such as Host, Accommodation, Activities, Management, Location, Hygiene and Cleanliness, Safety and Security, Marketing and Promotion, and Sustainability Principles are discussed.

\section{LITERATURE REVIEW}

\section{A. Homestay}

Kontogeorgopoulos, et. al (2015) address that homestays represent the process of commercializing one's home in order to utilize residential space for profitable purposes. As a form of accommodation, homestays occupy a middle ground between the intimate settings of a friend or family member's home and the purely commercial, informal environments found in hotels and other more conventional lodging facilities. Of course, entrepreneurial activity has long occurred in people's homes, but working from home is not quite the same as hosting strangers in one's home, because one involves engaging in commercial activities within the space of the home whereas the other transforms the very notion of "home" into a commercial space.

Based on the previous research conducted by Takran, et. al. (2017) about Thailand Homestay Standard assessment, it is not an easy task to prepare for the standard assessment. Homestay operators who are villagers are required to understand and interpret the assessment criteria. This is particularly acute for less educated and rural villagers who wish to have their homestay services assessed. Thus, it is highly likely that first-time submission would fail the assessment due to lack of preliminary examination from the experts. Moreover, the assessment takes place only once a year. Failing to pass the assessment means that it is another year of waiting.

Oranratmanee (2011) has said of rural-based homestays that the real, authentic experience of staying with a family, enjoying their hospitality, activities and pursuits, learning about different cultures, can best be found in rural areas, where people still have time and genuine friendship to offer to strangers. These rural-based characteristics, which allow one to experience the aspects of a local culture, distinguish rural homestays from those in other contexts.

\section{B. ASEAN Homestay Standard}

According to ASEAN Secretariat (2016), the objective of ASEAN Homestay Standard is to develop a comprehensive homestay standard that can be adapted by ASEAN Member States as recommended in the ASEAN Tourism Strategic Plan (ATSP): $2011-2015$ to create quality visitor experience by showcasing their rural resources in a presentable, safe, and attractive manner. The resulting standard will focus on nine criteria, namely host, accommodation, activities, management, location, hygiene 
and cleanliness, safety and security, marketing, and sustainability principles.

The homestay programme is a form of alternative tourism in which tourists are given the opportunity to experience the way of life in a typical village with local community. The experiential nature of this form of tourism is becoming increasingly popular with foreign tourists. In contrast to mass tourism, the homestay programme should preferably be low scale, low density, flexible and spontaneous. More importantly it should be owned and operated by the local communities so that the economic benefits go directly to them.

The success of the homestay programme in the ASEAN region is highly dependent on a strong understanding of the basic requirements of a quality visitor experience from a homestay perspective. Therefore the establishment of ASEAN Homestay standard is necessary, providing an opportunity to standardize a base level understanding of what a homestay is and to establish a minimum standard across all ASEAN member states. The standard also facilitates a coordinated approach, encouraging partnership with the relevant stakeholders, creating a positive environment while revitalizing the rural economy as well as poverty reduction. The standard focuses on the homestay, where guests will stay with the host's family and experience the everyday way of life of the family and community in both a direct and indirect manner. The standard also focuses on the following essential criteria such as host, accommodation, activities, authenticity, management, location, safety and security, marketing and sustainability principles.

Table 1 ASEAN Homestay Standard

\begin{tabular}{|c|c|c|c|}
\hline \multicolumn{2}{|r|}{ Criteria } & \multicolumn{2}{|r|}{ Sub-Criteria } \\
\hline \multirow[t]{2}{*}{1} & \multirow[t]{2}{*}{ Host } & 1.1 & $\begin{array}{l}\text { The village and } \\
\text { community }\end{array}$ \\
\hline & & 1.2 & Homestay provider \\
\hline \multirow[t]{3}{*}{2} & \multirow[t]{3}{*}{ Accommodation } & 2.1 & The house \\
\hline & & 2.2 & The bedroom \\
\hline & & 2.3 & The toilet, bathroom \\
\hline \multirow[t]{3}{*}{3} & \multirow[t]{3}{*}{ Activities } & 3.1 & $\begin{array}{c}\text { Village and communities } \\
\text { based activities }\end{array}$ \\
\hline & & 3.2 & Surrounding activities \\
\hline & & 3.3 & Authenticity \\
\hline \multirow[t]{5}{*}{4} & \multirow[t]{5}{*}{ Management } & 4.1 & Leadership \\
\hline & & 4.2 & Organisation \\
\hline & & 4.3 & Database \\
\hline & & 4.4 & $\begin{array}{l}\text { Capacity building and } \\
\text { training }\end{array}$ \\
\hline & & 4.5 & Collaboration \\
\hline 5 & Location & 5 & Accessibility \\
\hline \multirow[t]{3}{*}{6} & \multirow[t]{3}{*}{$\begin{array}{c}\text { Hygiene and } \\
\text { Cleanliness }\end{array}$} & 6.1 & $\begin{array}{l}\text { House (Kitchen, } \\
\text { bedroom, toilet) }\end{array}$ \\
\hline & & 6.2 & Surrounding compound \\
\hline & & 6.3 & Food preparation \\
\hline \multirow[t]{2}{*}{7} & \multirow{2}{*}{$\begin{array}{l}\text { Safety and } \\
\text { Security }\end{array}$} & 7.1 & Safety training \\
\hline & & 7.2 & $\begin{array}{l}\text { Safety features for } \\
\text { facilities/ activities }\end{array}$ \\
\hline
\end{tabular}

\begin{tabular}{|c|c|c|c|}
\hline \multirow{2}{*}{8} & 7.3 & $\begin{array}{c}\text { Briefing on safety } \\
\text { aspects }\end{array}$ \\
\cline { 3 - 4 } & & 7.4 & $\begin{array}{c}\text { Emergency rescue and } \\
\text { evacuation }\end{array}$ \\
\hline 8 & $\begin{array}{c}\text { Marketing and } \\
\text { Promotion }\end{array}$ & 8.1 & Promotion activities \\
\cline { 3 - 4 } & 8.2 & $\begin{array}{c}\text { Partnership with tour } \\
\text { operators }\end{array}$ \\
\cline { 3 - 4 } & $\begin{array}{c}\text { Sustainability } \\
\text { Principles }\end{array}$ & 8.3 & Web marketing \\
\cline { 3 - 4 } & 9.1 & Economic sustainability \\
\cline { 3 - 4 } & & 9.3 & $\begin{array}{c}\text { Environmental } \\
\text { sustainability }\end{array}$ \\
\hline
\end{tabular}

In order for a homestay in the ASEAN region to qualify for assessment, the homestay provider or homestay organization will have to fulfill certain requirements which are:

- The village shall have a minimum of 5 registered homestay providers

- The homestay provider shall be free of a criminal record

- The homestay provider shall be in good general health

In the case that a homestay provider or a homestay organization does not fulfill the related requirements mentioned above, it is immediately disqualified from applying the ASEAN Homestay. In order to measure the quality and performance of the homestays, The ASEAN Homestay Standard uses 9 main criteria and 27 sub-criteria containing 91 requirements.

The proposed benefits and privileges of being certified as an ASEAN Homestay are mostly related to better access to marketing and promotional programmes carried out by the related government agencies.

\section{Picture 1 Example of Certificate and Plaque}
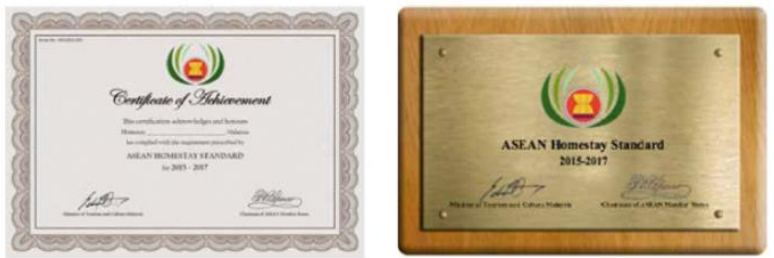

(Source: ASEAN Secretariat, 2016)

Essentially, certified homestays will benefit from the branding of ASEAN Standard Homestay which is an international recognition. The detailed benefits of certification are as follows:

- Issued with an ASEAN Homestay Standard certificate, logo and plaque to be displayed on the homestay premises

- Will be promoted in the ASEAN Organization Official website (http://www.asean.org) 
- Will be promoted at ASEAN and international tourism events, festivals and forums

- Priority listing on National Tourism Organization's websites and brochures

- Priority given to participate in national and international tourism fairs organized by National Tourism Organizations.

- Priority given to participate in free training programmes (tourist guide courses, etc.).

\section{METHODOLOGY}

This research used descriptive qualitative research method. Research subject is determined and selected deliberately according to research characteristics, namely homestay owners, tourism village management, and local government representative. The research informants are three homestay owners, one tourism village management, and one local government representative.

Data collection techniques in this research were used observation, interviews, documentation studies, and literature studies. Direct observation on place of research was conducted to record infrastructure and real condition in actual circumstances. After making an observation, data collected with interview technique by using interview guidelines. Indepth interview to three homestay owners, one tourism village management, and one local government representative were conducted. Check-list assessment from ASEAN Homestay Standard was used as the basis of observation and semi-structured interview guidelines. Other than that, researchers conducted literature studies from books, reports, journals, and documents in the form notes and photos and video. Researchers also search data through related documents and archives for local agencies.

\section{RESULTS AND DISCUSSIONS}

The results from synthesizing the assessment of the ASEAN Homestay Standard reveal qualitative indicators and requirements. The results could be subsequently used to identify gaps in homestays, which will help the key stakeholders in addressing the current shortcomings.

\section{A. Host}

Host indicator has two sub-indicators, namely The village and community and Homestay provider. This indicator related with distance between homestay and nearest nature and cultural attractions. The closer homestay to attractions, more credits homestay will get. In the case of Nglanggeran, homestays located in tourism village with its cultural attraction. The neighborhood some of homestays are used as cultural spots, such as painting mask with batik motif, handicrafts made of young coconut leaves, Jathilan and Reog traditional dance, catching fish, and planting rice. The nearest cultural attraction is painting mask with batik motif which is located in a house of village resident, just a few steps from some homestays. The farthest cultural attraction is planting rice which is located in rice field, about 500 metres from some homestays. The distance average between homestays and cultural attractions is 262 metres. Main attraction in Nglanggeran village are natural attractions. This village near Ancient Volcano and Embung (lake) Nglanggeran. Travelling time from homestays to ancient volcano (Gedhe Peak) is about 1.5 hours to 2 hours by trekking. While tourists have to walk from homestays to Embung Nglanggeran for 30 to 45 minutes.

This indicator also measure competition that village participate. Nglanggeran proudly won the best Tourism Village in the Southeast Asian region in ASEAN Community Tourism Award 2017. The main strength that this village have to won the competition is community involvement in developing tourism. This village is famous in Indonesia for its Community Based Tourism application. In the village there is a community centre or pendopo as required in this first indicator, where people can gather and hold village meeting. Tourism village management, homestay operators, handicrafts seller, and other stakeholders often gather in this place to discuss issues or problems raised.

Nglanggeran Tourism Village has not been able to measure the capacity of the homestay optimally. From more than 100 homestays, only 34 homestays were registered to tourism village management. This issue has to be carried out by tourism village management to push good homestay standard. In line with that issue, not all homestay providers have completed homestay course. From 34 registered homestays, just four of them took homestay course funded by an international NGO. Nevertheless, local government has planned to give homestay operators workshop about accommodation service and hygiene and sanitation.

\section{B. Accommodation}

Accommodation indicator has The house, The bedroom, and The toilet and bathroom as sub indicators. All Structure of house is in good and safe condition. Almost all building materials have good quality and some of them are new house. Yet, because some of homestays are new houses aimed only for tourists to sleep, design and building materials does not reflect local architecture and identity. Design and building materials of homestays only provide basic needs of accommodation facilities without considering using resident house or authentic traditional house.

Other than that, facilities of homestay meet basic requirement for accommodation. They have separate guest bedrooms and bathroom/ toilet, with average number of separate guest bedrooms and bathroom/ toilet are four to five bedrooms for each house. Homestays also have adequate electricity supply in the house and clean water supply inside the house. Homestays have basic amenities for tourists such as fan, desk, mini cupboard, mirror, electric socket, mosquito net, standard beds with mattresses and pillows, windows are fitted with a mesh frame, clean and fresh bed linen for every guest, squatting toilet inside and outside close the house. 


\section{Activities}

Activities indicator have Village and communities based activities, Surrounding activities, and Authenticity as sub indicators. Nglanggeran village showcases local resources such as local culture and heritage, local enterprises, and natural resources. Every activities also encourage interactive participation between the local community and guests because villager always guide tourists for almost activities. In every activities, tourists visits attractions in the surrounding areas and for some activities such as oil painting workshop will collaborates with surrounding villages in carryingout oil painting activities.

In developing tourism, community retains its identity, values, and culture. They always teach tourist to greet in local language and keep original lifestyle. Community tries to preserve and involve tourists in communal activities. Tourism village management involves tourists in creating handcrafts and showcase traditional arts in every tour package.

\section{Management}

Management indicator have Leadership, Organisation, Database, Capacity building and training, and Collaboration as sub indicators. Nglanggeran tourism village leader has strong leadership qualities and respected by local community. Although he does not want to be called leader, he is is well-known not only in the village but also in national level. He can be consider as 'local champion' who initiate and inspire other villagers to involve in tourism or welcome tourism development. However, there is no leader for homestay operators. Homestay operators just receive tourists at their house, all activities or programs are managed by tourism village management. The issue that arises is there no homestay representative in Nglanggeran Tourism Village management.

Tourism village management has registered homestay operator database and tourist's database. However, from more than 100 homestays only 34 homestays were registered in tourism village management. Tourism village management and Nglanggeran Village official always try to invite homestay operators to register their homestay.

Tourism village management has created simple manuals and guidelines covering welcoming and guest handling, hygiene and cleanliness, communication skills, planning, organizing and handling of activities, and storytelling and interpretation skills. However, homestay operators did not take these manuals into action. They just run the homestay as 'just business as usual' naturally.

\section{E. Location}

Location indicator consider accessibility as an important thing. Nglanggeran village is accessible to any mode of transportation. However, tourists will be difficult to see clear signage to guide guests to the homestay.

\section{F. $\quad$ Hygiene and Cleanliness}

Hygiene and Cleanliness indicator have House (kitchen, bedroom, toilet), Surrounding compound, and Food preparation as sub indicators. Regarding hygiene and cleanliness, tourists can not expect to compare homestay in Nglanggeran with star hotels. However, homestay operators try to consider hygiene and cleanliness as very important by doing clean up as best as they can. All rooms, kitchen, and toilets are clean (soap, shampoo, toilet tissue are not provided), disinfectants are used in toilets, and almost all surrounding compound is litter free.

Food for tourist, especially for group is provided by one kitchen. So, not every homestay provide food for tourist or give kitchen access for tourist. Kitchen is in good, clean condition and well ventilated. This way food preparation can be controlled by tourism village management. In serving foods, presentable plates and glasses are used in serving meals, fresh ingredients used in food preparation are sourced from local suppliers, and served food are properly covered. However, tourism village does not hygiene standard for food production. Villagers just cook foods same with their daily, there is no written standard of hygiene.

\section{G. Safety and Security}

Safety and security indicator have Safety training, Safety features for facilities/ activities, Briefing on safety aspects, and Emergency rescue and evacuation as sub indicators. This indicator is the most difficult to find in Nglanggeran because safety and security awareness for homestay operators is still low. Tourists can only find basic safety and security signage in ancient volcanic and Embung. Emergency/ first aid kit can on be found in information center in public area.

In every homestay, safety and security requirements that do not meet are safety personnel have undergone basic training infrst aid and emergency rescue, at least 2 safety personnel accompanyingguests during activities, water-based activity have safetyattire/equipments, physical facility have safety features, briefing on safety aspects prior to taking part in any related activity, leaflets on safety guidelines and tips areprovided, registering of guests participating in ecoadventure activities e.g. name and contact number, manual for safety procedures and guidelines as part of the Standard Operating Procedure (SOP), and insurance coverage for tourists.

\section{H. Marketing and Promotion}

Marketing and Promotion indicator have Promotion activities, Partnership with tour operators, and Web marketing as sub indicators. Packages are designed according to target markets needs and expectations. Target market of Nglanggeran are student group. Promotional materials, such as brochure, have been developed to attract schools to come and get 'live in' program in Nglanggeran. Tourism village management also cooperates with local government and tour operators for marketing. However, Nglanggeran still does not 
have familiarisation trips with tour operators and media. This program should be handled by government because the village still does not have sufficient budget.

To attract tourists to come, Nglanggeran tourism village does not have their own website. The only website from that area is offical website of Nglanggeran official (http://nglanggeran-patuk.desa.id/first). Village youth are involved in maintaining and updating online promotional materials by utilising social media to promote tourism village. Website fully controlled by village officilas and social media controlled by tourism village youth. There is no marketing promotion integration between website and social media. Online booking still difficult to be realised because of insufficient budget and professional IT expert to operate daily, especially for homestay operators.

\section{Sustainability Principle}

Sustainability principles indicator have Economic sustainability, Environmental sustainability, Sociocultural sustainability as sub indicators. Regarding economic sustainability, the homestay organisation employs staff from the local community, purchase materials and products from local farmers, tourists are requested to buy locally made goods, craft sales area within the homestay centre to showcase local products, and promote local festivals and visits to nearby markets. However, in Nglanggeran there no specific and written procedure to allocates incentives to motivate staff and provide micro fnance to deserving locals. However, local government have a plan to create 'cooperation' to tackle this issues.

Related with environmental sustainability, Nglanggeran village have code of conduct for tourists to protect environment. Local government limit physical impact of guests on ancient volcano and Embung. Local guide have to accompony every tourist trip to these two attractions. Code of conduct also discourage the participation of guests in activities which could exploit local flora and fauna. Tourism village management also often involved tourists in environmental programs such as litter clean ups and educate villager about the importance of conserving environment.

For sociocultural sustainability, in tourism village there is information centre which display local handicrafts and arts photographs. In code of conduct, beside environmental concern, socioculture also become something important. Tourists are being informed on the appropriate behaviour and the need to respect local customs and ban the participation of commercial sexual activities and illegal drug use. Tourism village management also educate local community about the importance of preserving their culture.

\section{CONCLUSION}

The results indicate that Nglanggeran has high potential to become a successful homestay destination but faces a few key challenges and constraints in term of the awareness of tourism village management and homestay operators. In order to overcome these challenges, there is a need to involve the community in tourism development scheme. There are various issues worth mentioning, such as homestays capacities, official registration, integration between marketing promotions with homestay facilities and activities, homestay representative in Nglanggeran Tourism Village management, and hygiene standard.

\section{REFERENCES}

[1] Aminudin, A. R. (2015). Pelaksanaan Pengelolaan Homestay Di Desa Lubuk Kembang Bunga Kawasan Eko Wisata Tesso Nilo Kabupaten Pelalawan Provinsi Riau. Journal of Tourism Studies Riau University, $1-9$.

[2] Andryanto, D. (2017, 01 27). Desa Wisata Nglanggeran Terbaik ASEAN 2017. Accessed inJuly 29, 2018, www.tempo.com: https://travel.tempo.co/read/838401/desa-wisata-nglanggeranterbaik-asean-2017.

[3] ASEAN Secretariat. (2016). ASEAN Homestay Standard.Accessed in July 29, 2018, from http://www.asean.org/storage/2012/05/ASEAN-HomestayStandard.pdf

[4] Badan Pembinaan Hukum Nasional. (2015, 01 01). Peraturan Daerah Nomor 1 Tahun 2012, Provinsi DI. Yogyakarta. Dipetik 07 29, 2018, dari http://www.bphn.go.id/data/documents/perda1-2012.pd www.bphn.go.id:

[5] Badan Pusat Statistik Provinsi DI. Yogyakarta. (2017). Provinsi Daerah Istimewa Yogyakarta Dalam Angka 2017. Yogyakarta: UD Sinar Baru Offset.

[6] Binnui, Anurak \& Iamsa ARD, Ninthana. (2016). Towards Sustainable Community- Based Tourism: A Case Of Homestay In Suratthani Province, Thailand. Proceedings of The IRES 27th International Conference, Pattaya, Thailand, 31st January 2016.

[7] Brohman, J. (1996). New directions in tourism for third world development. Annals of tourism research, 23(1), 48-70.

[8] Clayton, A., Oakley, P. \& Pratt, B. (1998). Empowering people: a guide to Participation. New York: UNDP.

[9] Cohen, E. (1988). Authenticity and commoditization in tourism. New York: Pergamon.

[10] Dinas Pariwisata Provinsi D.I. Yogyakarta. (2016). Destinasi Wisata Jogja. Yogyakarta: Dinas Pariwisata Provinsi DI. Yogyakarta.

[11] Handoko, S. (2018). Desa Wisata Nglanggeran Raih Penghargaan ASTA. Accessed in July 29, 2018, fromgunungapipurba.com:http://gunungapipurba.com/posts/detail/de sa-wisata-nglanggeran-raih-penghargaan-asta-asean-sustainabletourism-award-di-thailand

[12] Hermawan, H. (2016). Dampak Pengembangan Desa Wisata Nglanggeran Terhadap Ekonomi Masyarakat Lokal. Jurnal Pariwisata, 3(2), 105-117.

[13] Kayat, K. \& Nor, N. A. M. (2006). Penglibatan Ahli Komuniti Dalam Program Pembangunan Komuniti: Satu Kajian ke Atas Program Homestay di Kedah. Akademika, 67(1), 77-102.

[14] Kontogeorgopoulos, N., Churyen, A., \& Duangsaeng, V. (2015). Homestay tourism and the commercialization of the rural home in Thailand. Asia Pacific Journal of Tourism Research, 20(1), 29-50.

[15] Macek, I. C. (2012). Homestays as Livelihood Strategies in Rural Economies. Journal of Department of Urban Design and Planning, 50-62.

[16] Mertha, I. W. (2018). Homestay, Mozaik Pariwisata Berbasis Kerakyatan. Badung: Pusat Penelitian dan Pengabdian Kepada Masyarakat Sekolah Tinggi Pariwisata Nusa Dua-Bali.

[17] Middleton, V. (2001). Marketing in Travel and Tourism. London: Butterworth Heinemann.

[18] Nurmayanti, I. (2015). Potensi Wisata Di Desa Wisata Nglanggeran, Gunung Kidul, Yogyakarta. Jurnal Departemen Kehutanan, 18-28.

[19] Nurwafi, L. (2016). Dinamika Pembentukan Kelompok Sadar Wisata di Desa Wisata Nglanggeran. Jurnal ETD Gadjah Mada University, $1-13$. 
[20] Oranratmanee, R. (2011). Re-utilizing space: Accommodating tourists in homestay houses in northern Thailand. Journal of Architectural/Planning Research and Studies (JARS), 8(1), 35-54.

[21] Pitana, I. G. (2005). Sosiologi Pariwisata, Kajian Sosiologis Terhadap Struktur, Sistem dan Dampak-dampak Pariwisata. Yogyakarta: Ando Offset.

[22] Ratnaningtyas, Y. A., \& Widyasmoro, A. (2015). Pemasaran Desa Wisata Kalibuntung dalam Mendukung Pengembangan Pariwisata di Kabupaten Bantul Tahun ke 1 dari rencana 2 tahun.

[23] Salleh, M., Hanim, N., Othman, R., Nordin, N., Idris, M., Hajar, S., \& Shukor, M. S. (2014). The homestay program in Malaysia: Motivation for participation and development impact. Turizam: međunarodni znanstveno-stručni časopis, 62(4), 407-421.

[24] Takran, T., Chartrungruang, B., Tantranont, N., \& Somhom, S. (2017). Constructing a Thai Homestay Standard Assessment Mode by Implementing a Decision Tree Technique. International Journal of the Computer, the Internet and Management, 25(2), 106-112.

[25] Taylor, G. (1995). The community approach: does it really work? Tourism management, 16(7), 487-489.

[26] Vitasurya, V. R. (2017). Adaptive Homestay Sebagai Bentuk Partisipasi Masyarakat Untuk Melestarikan Desa Wisata Pentingsari Yogyakarta. Jurnal UAJY, 17-30

[27] Wahab, S. (2003). Manajemen Kepariwisataan. Jakarta: PT Pradana Paramita.

[28] Yasami, M., Awang, K. W. B., \& Teoh, K. (2017). Homestay Tourism: From The Distant Past Up To Present. People: International Journal of Social Sciences, 3(2). 